\title{
Metagenomic profiles of soil microbiota under two different cropping systems detected by STRs-based PCR
}

\author{
Massimo Zaccardelli", Domenica Villecco, Francesco Campanile, Catello Pane \\ CRA-Centro di Ricerca per l'Orticoltura, Via dei Cavalleggeri 25, Pontecagnano (SA), Italy; \\ *Corresponding Author: massimo.zaccardelli@entecra.it
}

Received 16 October 2011; revised 23 November 2011; accepted 16 December 2011

\begin{abstract}
In this research, soil microbial structures under a wheat triennial monoculture and horse beanwheat-horse bean succession were evidenced using a metagenomic approach. Polymorphism analysis of DNA extracted from soil samples collected at the end of the third year of the two crop successions, was performed by PCR, carried-out with six different primers designed on simple tandem repeats sequences. Readable profiles were obtained with M13 primer, from which no polymorphisms were detected, and with the primer $(\mathrm{GACA})_{4}$, that gave distinctive patterns. Experimental findings suggest that metagenomic analysis performed by (GACA $)_{4}$ primer may be an easy and suitable method to discriminate microbial diversity of different crop successions. (GACA) 4 PCR-pattern indicate that soil microbiota changes are well correlated with crop succession.
\end{abstract}

Keywords: Cover Plants; Hot-Spot Variability; Mini- and Micro-Satellite; PCR Fingerprinting;

Soil Biodiversity

\section{INTRODUCTION}

The soil is a highly complex and dynamic environment that sustain a great diversity of microbes associated to its biological properties [1]. Telluric biota is involved directly and indirectly in the provision of a wide range of ecosystem services, essential to land productivity, such as nutrient cycling and regulation of ecosystem processes [2]. For these reasons, the size of microbial diversity in the soil environment is, generally, directly related to global fertility and to its broad-spectrum quality [3]. Changes in soil microbial community structures occurred under different management practices, have been exten- sively explored with holistic approach by using various tools ranging from traditional plate counting until to innovative molecular-based techniques and "omic" strategies, including metagenomic analysis [4,5]. Newer researches to measure soil biodiversity, in fact, are focusing on genetic diversity viewed as the amount and distribution of genomic information within the generality of microbial species living in soil niches. Metagenomic strategy analyze the set of the total microbiota genomes, termed metagenome, extracted from indigenous community in a given soil [6,7]. This approach have a lot of credit respect to traditional methods that provide very limited information, because only a small percentage of total soil microbiota, estimated between $0.1 \%$ and $10 \%$, is cultivable in vitro $[1,8]$. Studies on microbiota diversity by molecular approach are increasing in this last years. In particular, studies were performed to evaluate the influence of soil type [9], the impact of a number of soil treatments, such as grassland restoration [10], saltrich water irrigation [11] or farm management style [12], on composition of telluric microbial community.

Among diverse analytical approaches that are known and described so far, polymerase chain reaction (PCR)based DNA fingerprinting technology applied to highly repeated sequences, randomly located within the whole genome, allow the rapid molecular characterization of soil microflora $[13,14]$.

These DNA sequences also include mini- and microsatellite regions that can be used to develop probe able to generate characteristic PCR-amplifed satellites fingerprints resolved by non-denaturing gel electrophoresis [15]. Minisatellites referred to as variable number of tandem repeats, include the core sequence of the wild type phage M13 (5'-GAGGGTGGCGGTTCT-3') [16], while microsatellites consist of simple or short sequence (di, tri, tetra etc.) repeats (SSRs), also referred to as simple tandem repeats (STRs), and include primers (GACA) $)_{4}[17,18]$, $(\mathrm{CA})_{8},(\mathrm{CT})_{8},(\mathrm{CAC})_{5},(\mathrm{GTG})_{5}[13]$ and $(\mathrm{GATA})_{4}[19]$.

Metagenomic analysis by PCR-amplifed mini- and 
microsatellites fingerprinting strategy was applied in this study to rigorously reveal genetic diversity of soil microbiota under two different cropping systems. Aim of this paper is to show metagenomic profiles of two compared soils that were cultivated with horse bean-wheat-horse bean succession and only with a wheat triennial homosuccession.

\section{MATERIALS AND METHODS}

\subsection{Soil Samples}

Soil samples were collected at a deep of $20 \mathrm{~cm}$ about three months after harvesting of wheat and horse-bean cultivated in the third year of a crop succession horse bean-wheat-horse bean (H-W-H) and a homosuccession of wheat (W). A total of six soil samples were collected from plots (three for each of the two crop successions) located at experimental farm of Battipaglia (CRA-ORT), in Southern Italy. Each soil sample, obtained mixing six sub-samples collected from the same plot, was sieved (sieve $2 \mathrm{~mm}$ ), dried at $40^{\circ} \mathrm{C}$ for $48 \mathrm{~h}$ and stored at room temperature.

\subsection{DNA Extraction and Purification}

DNA was extracted from $5 \mathrm{~g}$ of soil, in according to the protocol described previously [20]. DNA extracted was purified from humic acids by agarose gel electrophoresis. Concentration and purification of DNA were measured, respectively, by absorbance at 260 and $280 \mathrm{~nm}$ using a Bio-photometer (Eppendorf, Germany).

\subsection{Mini and Microsatellite Amplification}

It was performed by PCR using M13 minisatellite primer (5'-GAGGGTGGCGGTTCT-3') and (GACA) $)_{4}$, $(\mathrm{TGTC})_{4},(\mathrm{GTG})_{5},(\mathrm{CGA})_{5}$ and $(\mathrm{CCA})_{5}$ microsatellite primers. The primers used in this study were chosen among those that, previously, were successfully applied to differentiate genetic populations of various soil-borne microbes [21-25].

Each amplification was carried out in a volume of 25 $\mu 1$ containing $10 \mathrm{ng}$ of DNA, $0.2 \mathrm{mM}$ of dNTPs, $2.5 \mathrm{mM}$ of $\mathrm{MgCl}_{2}, 1 \mathrm{U}$ of Taq-DNA polymerase (Triple Master Taq, Eppendorf) and $50 \mathrm{ng}$ of primer. Amplification program was: $94^{\circ} \mathrm{C}$ for $30 \mathrm{~s}(60 \mathrm{~s}$ in the first cycle $), 50^{\circ} \mathrm{C}$ (for $\mathrm{M} 13$ primer) or $55^{\circ} \mathrm{C}$ (for all microsatellite primers) for $60 \mathrm{~s}, 72^{\circ} \mathrm{C}$ for $60 \mathrm{~s}$, for a total of 40 cycles. The thermocycler used was the Perkin Elmer 2400 model. For each DNA sample, amplifications were repeated 3 times.

\subsection{Electrophoresis and Staining}

Electrophoresis was performed in $1.5 \%$ agarose gel in
0.5 X TAE buffer, using electrophoretic cell GNA 200 model from Pharmacia Biotech. Run was done at $100 \mathrm{~V}$ for about 3 hours. Detection of the bands was made by ethidium bromide staining.

\subsection{Numerical Analysis of Band Patterns}

Looking amplification bands on the gels of the six DNA soil samples, a rectangular binary matrix $(1=$ presence of the band; $0=$ absence of the band) was constructed. Molecular markers used for to construct the matrix were the most stable, that were present in at least two out three soil samples (replications) for each succession. With the software numerical taxonomy NTSYS-PC version 2.0, from the binary rectangular matrix, a triangular similarity matrix was obtained using the Dice similarity coefficient (SD) and, after that, with the UPGMA (unweighted pair group method using arithmetic averages) clustering method, the dendrogram of similarity was constructed [26,27]. The structural diversity of soil bacteria were also assessed by Richness $(S)$ according to the following equations: $S=\sum S i / n$, where $S i$ is the total number of bands in each lane sample and $n$ is the total replicates [28].

\section{RESULTS AND DISCUSSION}

Genetic fingerprinting by PCR analysis of soil metagenome, based on the diversity of mini- and microsatellite sequences, revealed different ability of oligonucleotides to generate distinguishable profiles (Table 1). Readable patterns were obtained only with ColiphageM13 and (GACA) 4 primers while, for the other four primers, no well-defined profiles were detected. In fact, (TGTC $)_{4}$ oligonucleotide got unsuccessful and no band were displayed, while $(\mathrm{GTG})_{5},(\mathrm{CGA})_{5}$ and $(\mathrm{CCA})_{5}$ oligonucleotides generated a lot of not distinguishable bands, displaying smears on gel electrophoresis. M13PCR metagenomic fingerprinting resulted in complex banding pattern, containing generally about 15 visualized amplicons that were found identical for all analyzed soil samples. M13 primers resulted not able to discriminate between the two cropping systems and in spatial sampling (Figure 1).

On the contrary, complex and different band patterns were found with the $(\mathrm{GACA})_{4}$ oligonucleotide, able to discriminate among the two cropping systems regardless of the spatial variability of the sampling points (Figure 2). Considering the totality of (GACA) $)_{4}$-PCR profiles, a total of 43 well-resolved markers were detected. On electrophoresis gel were visualized, on average, about 17 bands for each profile which include few evident bands (about 14 on average). Together with this strong signals, a greater number of fainter well-resolved bands appeared in the profiles, determining some differences that were 
Table 1. Main characteristics of the primers used in PCR-based fingerprinting of soil metagenome and relative displayed gel-patterns.

\begin{tabular}{cccc}
\hline & \multicolumn{2}{c}{ PCR-based DNA Fingerprinting } \\
\hline Oligonucleotide characteristics & & \\
\hline M13 & Source & Sequence & PCR performance $^{(\mathrm{a})}$ \\
CCA-STRs & minisatellite & $5^{\prime}$-GAGGGTGGCGGTTCT-3 & Not-discriminating well-resolved bands \\
CGA-STRs & microsatellite & $(\mathrm{CCA})_{5}$ & Smear \\
GTG-STRs & $"$ & $(\mathrm{CGA})_{5}$ & Smear \\
TGTC-STRs & $"$ & $(\mathrm{GTG})_{5}$ & Smear \\
GACA-STRs & $"$ & $(\mathrm{TGTC})_{4}$ & Not amplified \\
\hline
\end{tabular}

$\mathrm{STR}_{\mathrm{S}}=$ simple tandem repeats sequences; ${ }^{(\mathrm{a})}$ Referred to results of displayed gel-patterns.

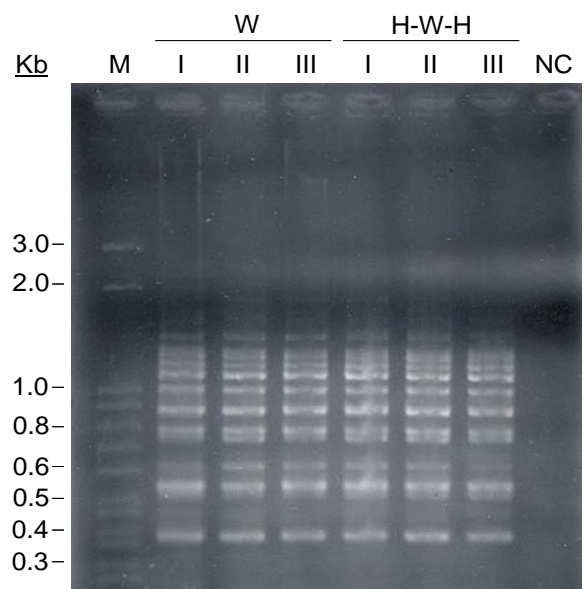

Figure 1. STRs fingerprints of PCR-amplifed phage M13 minisatellite sequence from directly extracted soil community DNA. Lanes: $\mathrm{W}$ soil and $\mathrm{H}-\mathrm{W}-\mathrm{H}$ soil samples with different spatial replicates (I, II e III).

all considered when clustering method was applied. According to (GACA) $)_{4}$-PCR fingerprinting soil microbial communities derived from $\mathrm{H}-\mathrm{W}-\mathrm{H}$ and $\mathrm{W}$ cropping systems grouped in separate clusters with a Dice's similarity coefficient of 0.58 ; the results of numerical analysis carried-out with the UPGMA method, are showed with the relative similarity dendrogram (Figure 3). Two soil communities profiles differ also for Richness (Table 2).

Furthermore, in our work, a striking diversity was observed in patterns of both tested soils, due to numerous faint bands in the background and to discordance of one of the three replicates. For both cropping systems, two out three replicates derived from the same soil utilization were largely similar, while the third was found with some differences, with a Dice's similarity coefficient of about 0.94 for both wheat 3-year monoculture and H-W-H succession.

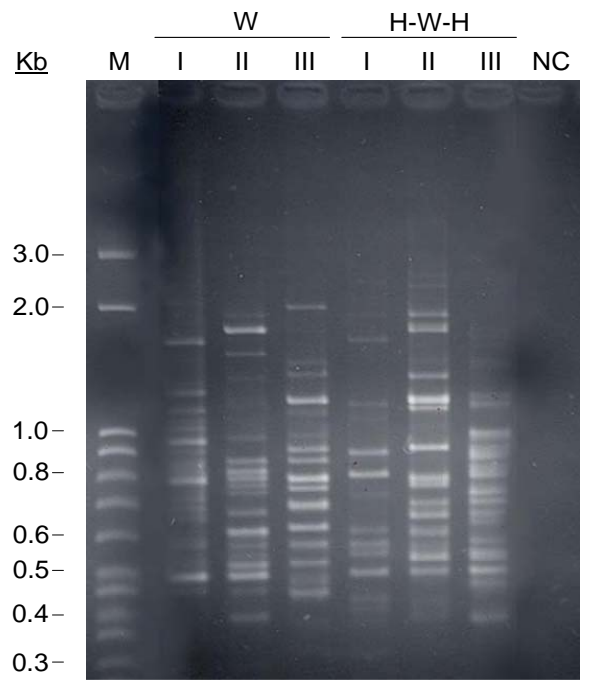

Figure 2. STRs fingerprints of PCR-amplifed $(\mathrm{GACA})_{4}$ microsatellite tandem sequence from directly extracted soil community DNA. Lanes: $\mathrm{W}$ soil and. H-W-H soil samples with different spatial sampling (I, II e III).

Table 2. Total bands generated by (GACA) $)_{4}$-PCR and visualized on electrophoresis gel with $2.5 \%$ agarose.

\begin{tabular}{ccccc}
\hline \multicolumn{5}{c}{ Number of bands detected in: } \\
\hline Soil communities & Rep I & Rep II & Rep III & Richness $^{(\text {a) }}$ \\
\hline W & 18 & 19 & 18 & $18.33 \pm 0.58$ \\
H-W-H & 15 & 17 & 17 & $16.3 \pm 1.15$ \\
\hline
\end{tabular}

${ }^{\text {(a) }}$ Means of three replicates (Rep.) \pm standard errors.

Amplification of repetitive microsatellite-DNA region through PCR using (GACA) $)_{4}$ primer was found a promising molecular tool for rapid and reliable soil metagenome fingerprinting. The utilization of these highly con- 


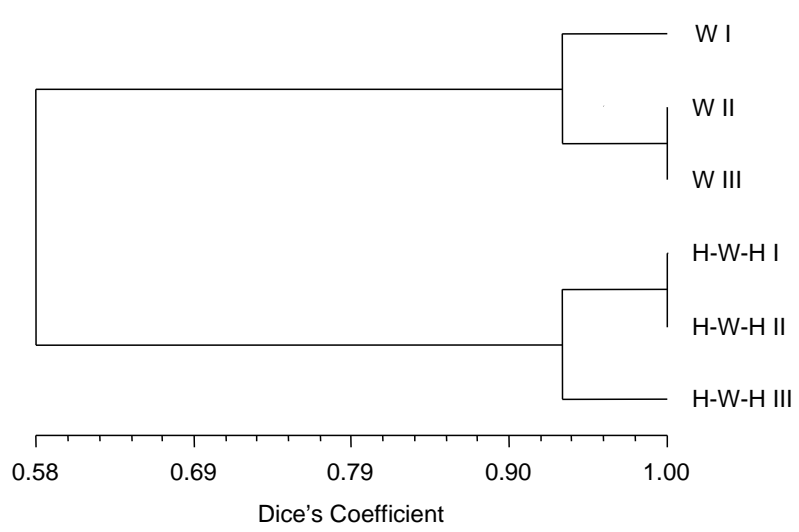

Figure 3. Cluster analysis (UPGMA, Dice's coefficient of similarity) of molecular banding patterns generated by (GACA $)_{4}$ PCR of Figure 2. The similarity dendrogram (scale 0-1) was calculated from lanes of all W or H-W-H replicates, for I, II and III spatial sampling.

served DNA-elements to study soil microbial diversity is not widespread, but our study demonstrate that this molecular approach can be adequate to the scope. Amplification failure and non-discriminating gel-patterns registered with M13, $(\mathrm{TGTC})_{4},(\mathrm{GTG})_{5},(\mathrm{CGA})_{5}$ and $(\mathrm{CCA})_{5}$ primers, suggest that the use of this method may be limited by the complexity of the communities and the suitability of the probe as previously reported [15].

The molecular approach used in this study consistently detected differences between the two compared cropderived soil communities, as confirmed by (GACA) $4^{-}$ PCR fingerprints cluster analysis, that suggest a strong and divergent impact of $\mathrm{H}-\mathrm{W}-\mathrm{H}$ rotation and $\mathrm{W}$ monoculture on microbial population. Likely, the different profiles observed in microbial structures of the two soils were due to plant-soil biota interactions and were driven by a trophyc resource utilization mechanism. Cover plants, in fact, could exert specific selective pressure on soil microbiota by root exudates deposition and decay of litter and roots, making available to microbes different C-pools [29] with substantial consequences on their genetic structure. The evidences suggest that the diverse cropping system is the main cause of microbial structure changes observed in this study. This is in agreement with earlier studies which hypothesized that cover plants may affect telluric microbial population [30-33].

Furthermore, the particular spatial distribution of microbiota detected among replicates into each group, evidenced that the structure of microbial communities, derived from the two soil utilization types, was rather complex and was affected by slight variability in the space. Nevertheless, PCR-pattern analysis revealed that prolonged cover plant pressure, such as that pursued by a forage crop, allow to overcame naturally space-structured variability existing into soil community. At the scale at which microbes perceive their environment, most microbial habitats are spatially heterogeneous, due to a large number of potential niches. These microhabitats, together create different islands of soil biological activity and better known as hot-spots that can have profound effects on the functional and phylogenetic microbial structure [34,35]. Therefore, findings of this work agree on the conclusive hypothesis that intensive cropping systems may contribute also to smooth out soil patchiness and make soil microbiological conditions more homogeneous. Moreover, soil microbiota changes, detected by analysis of the metagenome, are well correlated with cover plants sown in succession. This paper let to conclude that the use of PCR amplified short tandem repeat sequences, derived from total environmental DNA, may be a good molecular approach to obtain fingerprints of microbial community changes and to calculate microbial diversity indicators. Although these high variable repetitive DNA sequences were indicated as possible markers for soil microbial genetic fingerprinting [15], in literature there is a gap about experimental evidences that support this application. Therefore, this work investtigated the potential use of these selected specific STRs as fingerprinting method at community level too. However, further studies are necessary to compare the performances of the proposed methodology with major standard fingerprinting methods used for microbial community analysis and will be particularly useful to extend the base of the research to a larger number of case studies with more than two treatments, in order to strengthen the reliability of the method.

\section{ACKNOWLEDGEMENTS}

Funding for this research was provided by Mi.P.A.A.F.

\section{REFERENCES}

[1] Torsvik, V. and Øvreås, L. (2002) Microbial diversity and function in soil: From genes to ecosystems. Current Opinion in Microbiology, 5, 240-245. doi:10.1016/S1369-5274(02)00324-7

[2] Barrios, E. (2007) Soil biota, ecosystem services and land productivity. Ecological Economics, 64, 269-285. doi:10.1016/j.ecolecon.2007.03.004

[3] Pane, C., Villecco, D., Pentangelo, A., Lahoz, E. and Zaccardelli, M. (2011) Integration of soil solarization with Brassica carinata seed meals amendment in a greenhouse lettuce production system. Acta Agriculturae Scandinavica, Section B-Soil \& Plant Science. doi:10.1080/09064710.2011.613850

[4] Nannipieri, P., Ascher, J., Ceccherini, M.T., Landi, L., Pietramellara, G. and Renella, G. (2003) Microbial diversity and soil functions. European Journal of Soil Science, 54, 655-670. doi:10.1046/j.1351-0754.2003.0556.x

[5] Maron, P.A., Mougel, C. and Ranjard, L. (2011) Soil 
microbial diversity: Methodological strategy, spatial overview and functional interest. Comptes Rendus Biologies, 334, 403-411. doi:10.1016/j.crvi.2010.12.003

[6] Rondon, M.R., August, P.R., Bettermann, A.D., Brady, S.F., Grossman, T.H., Liles, M.R., Loiacono, K.A., Lynch, B.A., MacNeil, I.A., Minor, C., Tiong, C.L., Gilman, M., Osburne, M.S., Clardy, J., Handelsman, J. and Goodman, R.M. (2000) Cloning the soil metagenome: A strategy for accessing the genetic and functional diversity of uncultured microorganisms. Applied and Environmental Microbiology, 66, 2541-2547. doi:10.1128/AEM.66.6.2541-2547.2000

[7] Handelsman, J., Rondon, M.R., Brady, S.F., Clardy, J. and Goodman R.M. (1998) Molecular biological access to the chemistry of unknown soil microbes: A new frontier for natural products. Chemistry \& Biology, 5, 245-249. doi:10.1016/S1074-5521(98)90108-9

[8] Kell, D.B., Kaprelyants, A.S., Weichart, D.H., Harwood, C.R. and Barer, M.R. (1998) Viability and activity in readily culturable bacteria: A review and discussion of the practical issues. Antonie van Leeuwenhoek, 73, 169-187. doi:10.1023/A:1000664013047

[9] Fierer N., Jackson, J.A., Vilgalys, R. and Jackson, R.B. (2005) Assessment of Soil Microbial Community Structure by Use of Taxon-Specific Quantitative PCR Assays. Applied and Environmental Microbiology, 71, 4117-4120. doi:10.1128/AEM.71.7.4117-4120.2005

[10] Plassart, P., Vinceslas, M.A., Gangneux, C., Mercier, A., Barray, S. and Laval, K. (2008) Molecular responses of soil microbial communities under grassland restoration. Agriculture, Ecosystems and Environment, 127, 286-293. doi:10.1016/j.agee.2008.04.008

[11] Crecchio, C., Gelsomino, A., Ambrosoli, R., Minati, J.L. and Ruggiero, P. (2004) Functional and molecular responses of soil microbial communities under differing soil management practices. Soil Biology \& Biochemistry, 36, 1873-1883. doi:10.1016/j.soilbio.2004.05.008

[12] Lopes, A.R., Faria, C., Prieto-Fernandez, Á., Trasar-Cepeda, C., Manaia, C.M. and Nunes, O.C. (2011) Comparative study of the micobial diversity of bulk paddy soil of two rice fields subjected to organic and conventional farming. Soil Biology \& Biochemistry, 43, 115-125. doi:10.1016/j.soilbio.2010.09.021

[13] Versalovic, J., Koeuth, T. and Lupski, J.R. (1991) Distribution of repetitive DNA sequences in eubacteria and application to fingerprinting of bacterial genomics. Nucleic Acid Research, 19, 6823-6831. doi:10.1093/nar/19.24.6823

[14] Thies, J.E. (2004) Eco-biological soil assessment: Analytical approaches through molecular methods. Procedings of I International Conference: Soil and compost eco-biology. 15-17 September 2004, León, Spain.

[15] Kirk, J.L., Beaduette, L.A., Hart, M., Moutoglis, P., Klironomos, J.N., Lee, H. and Trevors, J.T. (2004) Methods of studying soil microbial diversity. Journal of Microbiological Methods, 58, 169-188. doi:10.1016/j.mimet.2004.04.006

[16] Vassart, G., Georges, M., Monsieur, R., Brocas, H., Lequarre, AS. and Christophe, D. (1987) A sequence in M13 phage detects hypervariable minisatellites in human and animal DNA. Science, 235, 683-684. doi:10.1126/science. 2880398

[17] Epplen, J.T. (1988) On simple repeated GATCA sequences in animal genomes: A critical reappraisal. Journal of Heredity, 79, 409-417.

[18] Ali, S., Muller, C.R. and Epplen, J.T. (1986) DNA fingerprinting by oligonucleotide probes specific for simple repeats. Human Genetics, 74, 239-243. doi:10.1007/BF00282541

[19] Vogel, J.M. and Scolnik, P.A. (1997) Direct amplifications from microsatellites: Detection of simple sequence repeat-based polymorphisms without cloning. In: Caetano-Anollés, G. and Gresshoff, P.M., Eds., DNA Markers: Protocols, Applications and Overviews, Wiley, John and Sons, New York, 133-150.

[20] Zhou, J., Bruns, M.A. and Tiedje, J.M. (1996) DNA recovery from soils of diverse composition. Applied and Environmental Microbiology, 62, 316-322.

[21] Khashnobish, A., Hamann, A. and Osiewacz, H.D. (1999) Modulation of gene expression by (CA)n microsatellites in the filamentous ascomycete Podospora anserina. Applied Microbiology and Biotechnology, 52, 191-195. doi: $10.1007 / \mathrm{s} 002530051508$

[22] Yurkov, A.M. and Chernov, I.Y. (2005) Geographical Races of Certain Species of Ascomycetous Yeasts in the Moscow and Novosibirsk Regions. Microbiology, 74, 597-601. doi:10.1007/s11021-005-0108-6

[23] Harish, S., Kavino, M., Kumar, N., Balasubramanian, P. and Samiyappan, R. (2009). Induction of defense-related proteins by mixtures of plant growth promoting endophytic bacteria against Banana bunchy top virus. Biological Control, 51, 16-25. doi:10.1016/j.biocontrol.2009.06.002

[24] Anderson, I., Chambers, S. and Cairney, J. (2009) Taxonomy and population biology of South-Eastern Australian Pisolithus species. Australasian Mycologist, 18, 37.

[25] Midgley, D., Chambers, S., Liu, G., Williams, A. and Cairney, J. (2009) Molecular determination of diversity in ericoid mycorrhizal endophytes from Woollsia pungens (Cav.) F. Muell. (Epacridaceae). Australasian Mycologist, 18, 39.

[26] Sneath, P.H.A. and Sokal, R.R. (1973) Numerical Taxonomy: The principles and practice of numerical classification, San Francisco, freeman, 573.

[27] Vauterin, L. and Vauterin, P. (1992) Computer-aided objective comparison of electrophoresis patterns for grouping and identification of microorganisms. European $\mathrm{Mi}$ crobiology, 1, 37-42.

[28] Wang, Y., Shi, J., Wang, H., Lin, Q., Chen, X. and Chen, Y. (2007) The influence of soil heavy metals pollution on soil microbial biomass, enzyme activity, and community composition near a copper smelter. Ecotoxicology and Environmental Safety, 67, 75-81. doi:10.1016/j.ecoenv.2006.03.007

[29] Brimecombe, M.J., De Leij, F.A. and Lynch, J.M. 2001. The effect of root exudates on rhizosphere microbial populations. In: Pinton, R., Varaninin, Z. and Nannipieri, 
P., Eds., The Rhizosphere: Biochemistry and Organic Substances at the Soil-Plant Interface, M. Dwekker, New York, 95-140.

[30] Grayston, S.J., Shenquiang, W., Campbell, C.D. and Edwards, A.C. (1998) Selective influence of plant species on microbial diversity in the rhizosphere. Soil Biology \& Biochemistry, 30, 369-378. doi:10.1016/S0038-0717(97)00124-7

[31] Larkin, R.P. and Honeycutt, C.W. (2006) Effects of different 3-year cropping systems on soil microbial communities and Rhizoctonia diseases of potato. Phytopathology, 96, 68-79. doi:10.1094/PHYTO-96-0068

[32] Srivastava, R., Roseti, D. and Sharma, A.K. (2007) The evaluation of microbial diversity in a vegetable based cropping system under organic farming practices. Applied
Soil Ecology, 36, 116-123. doi:10.1016/j.apsoil.2007.01.008

[33] Acosta-Martínez, V., Dowd, S.E., Bell, C.W., Lascano, R., Booker, J.D., Zobeck, T.M. and Upchurch, D.R. (2010) Microbial community composition as affected by dryland cropping systems and tillage in a semiarid sandy soil. Diversity, 2, 910-931. doi:10.3390/d2060910

[34] Ettema, C.H. and Wardle, D.A. (2002) Spatial soil ecology. Trends in Ecology and Evolution, 17, 177-183. doi:10.1016/S0169-5347(02)02496-5

[35] Fierer, N. (2008) Microbial biogeography: Patterns in microbial diversity across space and time. In: Zengler, K., Ed., Accessing Uncultivated Microorganisms: From the Environment to Organisms and Genomes and Back, ASM Press, Washington DC, 95-115. 